\title{
Export Mode Heterogenicity and Enterprise Productivity -A Test about Learning by Exporting
}

\author{
Xiaolong Zhang \\ School of Economics, Jinan University, Guangzhou, China \\ Email: zhangxiaolongjn@163.com
}

Received 30 December 2015; accepted 23 January 2016; published 26 January 2016

Copyright (C) 2016 by author and Scientific Research Publishing Inc.

This work is licensed under the Creative Commons Attribution International License (CC BY).

http://creativecommons.org/licenses/by/4.0/

(c) (i) Open Access

\begin{abstract}
Based on the theory of heterogeneous enterprise trade and enterprise micro-data, this paper investigates the influence of direct export and indirect export on enterprise productivity, and explains the knowledge spillovers of the hypothesis of "learning by exporting" from the perspective of the relationship between export and enterprise productivity. Empirical results show that: direct export improves enterprise productivity which increased with the rising of direct export intensity. By contrast, indirect export exerts little influence on enterprise productivity. We conclude that direct export is an important channel for "learning by exporting" which is of great significance to improvement of enterprise productivity.
\end{abstract}

\section{Keywords}

Enterprise Productivity, Direct Export, Indirect Export

\section{Introduction}

More enterprises are entering global market for better profits and higher productivity with the increasingly rapid progress of economic globalization. Domestic and foreign scholars have paid high attention to micro-level investigation on relationship between export and enterprise productivity in recent years. Their researches were mainly about two hypotheses on the basis of heterogeneous enterprise trade theory. The first was "self-selection" hypothesis which assumes that only enterprises with high productivity are able to afford sunk costs for participating in international trade in the export market. The second was the hypothesis of "learning by exporting" which is about the positive role of export in promoting enterprise productivity.

Bernard \& Jensen (1999) [1] examined whether enterprises with good business performance had bigger export volumes and whether their business performance became better by analyzing related data of USA from 
1984 to 1992. Analysis indicated that “self-selection” effect existed in exports made by enterprises but the effect of "learning by exporting" was not so obvious. Clerides et al. (1998) [2] verified the notable positive correlation between enterprise productivity and export by using data of Columbia, Mexico and Morocco, but export did not significantly improve productivity. Melitz (2003) [3] built a dynamic intra-industry model of heterogeneous manufacturers by combining Hopenhayn’s dynamic industry model with Krugaman's intra-industry trade model. He held that potential manufacturers paid for sunk costs to enter market and all of them faced an invariable exogenetic probability of exit. Exogenetic distribution functions defined a constant productivity for each manufacturer. Manufacturers under monopolistic competition would choose to exit the industry when their productivity was below a critical value, but they would export products for more profits when their productivity reached a certain high level. Sunk costs were higher in export market than in domestic market. Analysis showed that only manufacturers with high productivity would choose to enter export market while those with low productivity just focused on domestic market. Moreover, trades would force manufacturers with the lowest productivity to exit the market. Melitz's research laid the foundation of new-new trade theory. On this basis, Bernard et al. (2003) [4], Baldwin (2005) [5] and Ghironi \& Melitz (2005) [6] made modification and extension to the dynamic intra-industry model from different perspectives respectively. All their researches supported the hypothesis of "self-selection".

There are fewer literatures about "learning by exporting” compared with those supporting "self-selection”. Bigsten et al. (2004) [7] and Van Biesebroeck (2005) [8] proved the effect of "learning by exporting” by investigating sub-Saharan African countries. The study conducted by De Loecker (2007) [9] also supported the "learning by exporting" hypothesis and found the effect of "learning by exporting” in 13 among 16 investigated industries. Greenaway \& Kneller (2008) [10] discovered that export noticeably facilitated enterprise productivity by analyzing data from British manufacturing enterprises from 1988 to 2000. Aw et al. (2000) [11] stated in the same thesis that the effect of "learning by exporting” was found in Chinese Taipei, not in South Korea.

Lileeva \& Trefler (2010) [12] argued that inadequate evidence for "learning by exporting” was probably because previous researches did not consider the original heterogeneity of enterprise productivity and the heterogeneity of improving productivity during investments. There was a great difference in "learning by exporting” and the learning speed and degree among different countries, regions, industries and enterprises. Thus variance in samples and empirical approaches may result in different research results. On the basis of previous studies, the paper verifies the effect of "learning by exporting" only generated from direct export of Chinese manufacturers from the perspective of heterogeneity of export models.

\section{Variable Selection, Model Specification and Regression Analysis}

\subsection{Variable Selection}

\section{1) Gross output}

As the World Bank did not provide gross output values of enterprises in its database. However, since LnY denotes the log value of added outputs in this paper, sample business inventories are basically flat compared to that of last year. Under the situation that sample business inventories are nondecreasing, the added value of the sales revenue includes all enterprise's added outputs. so gross output index in this paper is replaced by gross annual sales and its logarithm (LnY) is interpreted as variable.

2) Direct export and indirect export

In the database of the World Bank, investigated Chinese enterprises provided data about their gross sales and shares of domestic sale, direct export and indirect export. These data can be used to calculate amount of direct export (DE) and indirect export (IDE). It should be noted that non-exporters in this paper refer to enterprises that make $100 \%$ of sales in domestic market; indirect exporters refer to enterprises that have a positive ratio of indirect export and zero ratio of direct export; and direct exporters refer to enterprises that have a positive ratio of direct export and zero ratio of indirect export.

3) Control variables

On one hand, enterprise productivity is also influenced by other knowledge and channels. On the other hand, China is a large economic entity. Enterprises in different industries and regions may noticeably differ from each other in productivity. Therefore, the paper introduces as many control variables as possible in models to control other influencing factors on enterprise productivity and to adapt to heterogeneity of enterprises on the premise of available data. Control variables include: 1) foreign direct investments (FDI): Caves 1974 [13], Globerman 1979 
[14] and Aitken \& Harrison 1999 [15] found in their researches that industries and enterprises with higher ratio of FDI had higher outputs. Chen Lin and Luo Changyuan 2011 [16] studied the panel data of micro-enterprises and discovered that FDI improved productivity of Chinese enterprises through forward linkage. 2) R\&D investments: a majority of researches proved that R\&D obviously promoted productivity. Wu Yanbing 2006 [17] conducted empirical test and verified that R\&D had a noticeable positive effect when other factors were under control. Thus the paper introduces $R \& D$ investments (dummy variable) as a control variable into regression function. 3) Enterprise age (AGE): existence time of an enterprise is a measurement for its management experience and learning capacity. This paper predicts there is a noticeably positive correlation between enterprise age and productivity. 4) Capital utilization (CU): used to control the average utilization ratio of fixed inputs. 5) $\mathrm{Hu}-$ man capitals (HU): accumulation of human capitals can not only enhance craftsmanship and productivity but also improve technical absorption efficiency and technological innovation ability, indirectly increasing enterprise productivity.

We believe that enterprises in same industries or with similar regional backgrounds may have common in one or more than one features as data from multi-industry and trans-regional enterprises are used in this paper. More obvious homogeneity is found in enterprises in same industries or with similar regional background than multi-industry enterprises or those with different regional backgrounds due to observable and unobservable factors. Region and industry are used as two dummy variables in order to decrease the possibility of estimation error. Major variables are illustrated in Table 1.

\subsection{Model Specification}

This paper aims to use samples of Chinese manufacturing enterprises to study whether direct and indirect exporters have higher productivity level than enterprises not engaged in exports. To do this, we estimate following production function:

$$
Y=\int(K, L, M, E N, D E, I D E, \text { Control }) .
$$

where the left side of the function denotes gross output and the right side denotes various inputs and other technical elements influencing gross output. The model is used to control variables influencing output and investigate the productive difference between enterprises with heterogeneity of export models. According to assumption, influence of explaining variables on output level reflects the influence on enterprise productivity on the condition that other factors are under control. In order to make estimation, assume that the production function can be rewritten as Cobb-Douglas equation:

$$
L n Y_{i}=\alpha_{0}+\alpha_{1} L n L_{i}+\alpha_{2} L n K_{i}+\alpha_{3} L n M_{i}+\alpha_{4} L n E N_{i}+\alpha_{5} D E_{i}+\alpha_{6} I D E_{i}+\sum_{n} \beta_{n} \operatorname{Control}_{n i}+\mu_{i} .
$$

\begin{tabular}{|c|c|c|c|}
\hline Variable type & Symbols & Meanings & Description \\
\hline $\begin{array}{l}\text { Dependent } \\
\text { variables }\end{array}$ & LnY & Log value of gross output & Gross output replaced by gross annual sales \\
\hline \multirow{2}{*}{$\begin{array}{l}\text { Explaining } \\
\text { variables }\end{array}$} & $\mathrm{DE}$ & Direct export & Dummy variable: $D E=1$, direct export; $D E=0$, non-direct export \\
\hline & IDE & Indirect export & Dummy variable: $I D E=1$ indirect export; $I D E=0$, non-indirect export \\
\hline \multirow{7}{*}{$\begin{array}{c}\text { Control } \\
\text { variables }\end{array}$} & FDI & Foreign direct investments & $\begin{array}{l}\text { Dummy variable: } F D I=1 \text {, foreign direct investment available } \\
F D I=0 \text {, no foreign direct investment }\end{array}$ \\
\hline & $\mathrm{RD}$ & $\begin{array}{l}\text { Research and } \\
\text { development investments }\end{array}$ & $\begin{array}{l}\text { Dummy variable: } \\
\mathrm{RD}=1 \text {, R\&D investments available in the last } 3 \text { years } \\
\mathrm{RD}=0 \text {, no } \mathrm{R} \& \mathrm{D} \text { investments available in the last } 3 \text { years }\end{array}$ \\
\hline & LnCU & Capital utilization & Ratio of actual outputs in current year in potential maximum outputs \\
\hline & LnHU & Human capitals & Average years of education of staff \\
\hline & LnAGE & Enterprise age & Existence years of enterprises \\
\hline & RG & Region & Dummy variable: $R G=1$, provincial capital, non-capital cities \\
\hline & ID & Industry & Dummy variable \\
\hline
\end{tabular}

where $i$ denotes an enterprise, and $\operatorname{LnY}$ denotes the $\log$ value of gross output. $\operatorname{LnL}, \operatorname{LnK}, \operatorname{LnM}$, and 
LnEN represent log values of capital input, labor input, raw materials input and energy input respectively.

$\mathrm{DE}$ is a dummy variable denoting direct exporter $(D E=1$, direct export; $D E=0$, non-direct export); $I D E$ is also a dummy variable denoting indirect exporter (IDE $=1$ indirect export; $I D E=0$, non-indirect export); and $\mu$ represents random error. $\alpha_{5}$ and $\alpha_{6}$ indicate the productive difference between direct exporters and enterprises not engaged in exports and that between indirect exporters and enterprises not engaged in exports respectively. Just as the estimated results in the theoretical analysis above, the expected empirical results are: estimation value of $\alpha_{5}$ is positive and of great statistical significance while that of $\alpha_{6}$ is positive but of minor statistical significance.

\section{Data Declaration and Regression Analysis}

\subsection{Data Declaration and Sample Treatment}

Data used in this paper are 2011 survey data about Chinese enterprises published by the World Bank in 2013 after conducting face-to-face interviews with enterprises. Simple random sampling or stratified random sampling was used in the survey to ensure the randomness of samples. Certain sampling methods were designed to select enterprises that were representative in industry, scale ownership, export and region.

In order to ensure validity, data are processed as follows: data lacking export information and from enterprises in non-manufacturing and unknown industries are deleted to ensure that all variables including output, fixed assets and number of wage laborers are positive. The valid samples are consisted of 1578 private manufacturers from 11 manufacturing industries covering food, textile, clothing and chemicals in 25 prefecture-level cities. These samples are decomposed into domestic market enterprises, direct exporters and indirect exporters according to their export models.

\subsection{Statistical Description}

There are 1060 or $67.3 \%$ domestic market enterprises, 331 or $16.5 \%$ direct exporters and 187 or $16.2 \%$ indirect exporters among the total 1578 valid samples.

Before estimating the function (1), we firstly conduct comparative analysis on the mean value of domestic market enterprises, direct exporters and indirect exporters and set domestic market enterprises as baseline group. The mean value t of direct exporters and indirect exporters is inspected respectively, and the results are shown in Table 2.

Comparative analysis on inspection results in Table 2 shows that exporters (direct \& indirect) are clearly different from non-export enterprises in terms of output and traditional input factors. DE and IDE are much higher than non-export enterprises in such traditional productive input factors as capitals, labors, raw materials and energy. DE is clearly different from non-export enterprises in unproductive factors that determine enterprise productivity, while the difference between IDE and non-export enterprises is minor.

DE are 0.019 (4.466 - 4.447) higher than non-export enterprises in capital utilization (log values), and the

Table 2. Test of mean difference.

\begin{tabular}{ccccc}
\hline Variables & Baseline group & DE & IDE & Complete sample \\
\hline LnY & 16.659 & $17.841^{* * *}$ & $16.907^{* *}$ & 16.936 \\
LnL & 4.249 & $5.143^{* * *}$ & $4.545^{* *}$ & 4.471 \\
LnK & 15.391 & $16.252^{* * *}$ & $15.790^{* *}$ & 15.619 \\
LnM & 15.370 & $16.598^{* * *}$ & $15.878^{* * *}$ & 15.687 \\
LnEN & 13.301 & $13.994^{* * *}$ & $13.445^{* * *}$ & 13.462 \\
LnAGE & 2.430 & 2.451 & 2.460 & 2.438 \\
LnCU & 4.447 & $4.466^{* *}$ & 4.455 & 1366 \\
LnHU & 2.299 & $2.323^{* * *}$ & 2.274 & 1541 \\
RD & 0.368 & $0.612^{* *}$ & 0.530 & 1548 \\
FDI & 0.040 & $0.188^{* * *}$ & $0.080^{* * *}$ & 1546 \\
\hline
\end{tabular}

Notes: ${ }^{* * *},{ }^{* *},{ }^{*}$ indicate noticeable mean difference under significance level of $1 \%, 5 \%$ and $10 \%$, respectively. 
difference is significant in statistics; and the former is much higher than the latter in terms of average years of education of staff (log values). Table 2 also indicates that 18.8\% of DE and $8.0 \%$ of IDE receive FDI, both higher than non-export enterprises. In terms of RD, ratio of enterprises that had RD in the last three years differs greatly among $\mathrm{DE}$ and non-export enterprises. The ratio of enterprises that had $\mathrm{RD}$ is much higher in $\mathrm{DE}$ than in non-export enterprises and IDE.

Further analysis discovers that log value (LnY) of output level average 17.841 and 16.907 in DE and IED respectively, both higher than the 16.659 in non-export enterprises. However, comparison finds that average values of characteristic variables of IDE are largely between those of non-export enterprises and those of DE. Overall, difference between DE and non-export enterprises is more noticeable than that between IDE and non-export enterprises.

\subsection{Result}

Least square regression is used in the function (2) in order to estimate the contributions of different export models (DE and IDE) to productivity. Results are shown in Table 3. As the log values of output are treated as explained variable in this paper, $\alpha_{5}$ and $\alpha_{5}$ represent the average percentage variation between DE and nonexport enterprises and that between IDE and non-export enterprises respectively. Thus, $\alpha_{5}$ and $\alpha_{6}$ in the function (1) and significance level can be used to judge whether DE or IDE mainly account for the effect of "learning by exporting" among Chinese exporters.

As many independent variables are used in models, variance inflation factors (VIF) are used to check multicollinearity before employing OLS regression in the function (1) in order to avoid possible influence caused by

Table 3. Regression results.

\begin{tabular}{|c|c|c|}
\hline \multirow{2}{*}{$\begin{array}{c}\text { Variables } \\
\text { LnL }\end{array}$} & \multicolumn{2}{|c|}{ Coefficient and significance level } \\
\hline & $0.337^{* * *}$ & $0.342^{* * *}$ \\
\hline & $(0.023)$ & $(0.023)$ \\
\hline \multirow[t]{2}{*}{ LnK } & $0.041^{* * *}$ & $0.040^{* * *}$ \\
\hline & $(0.015)$ & $(0.015)$ \\
\hline \multirow[t]{2}{*}{ LnM } & $0.498^{* * *}$ & $0.499^{* * * *}$ \\
\hline & $(0.018)$ & $(0.018)$ \\
\hline \multirow[t]{2}{*}{ LnEN } & $0.161^{* * *}$ & $0.157^{* * *}$ \\
\hline & $(0.017)$ & $(0.018)$ \\
\hline \multirow[t]{2}{*}{$\mathrm{DE}$} & $0.099^{*}$ & $0.098^{*}$ \\
\hline & $(0.054)$ & $(0.055)$ \\
\hline \multirow[t]{2}{*}{ IDE } & 0.019 & 0.034 \\
\hline & $(0.065)$ & $(0.067)$ \\
\hline \multirow[t]{2}{*}{ LnAGE } & $0.067^{*}$ & $0.067^{*}$ \\
\hline & $(0.040)$ & $(0.040)$ \\
\hline \multirow[t]{2}{*}{$\mathrm{LnCU}$} & 0.117 & 0.116 \\
\hline & $(0.111)$ & $(0.112)$ \\
\hline \multirow[t]{2}{*}{ LnHU } & $0.560^{* * *}$ & $0.510^{* * * *}$ \\
\hline & $(0.100)$ & $(0.102)$ \\
\hline \multirow[t]{2}{*}{$\mathrm{RD}$} & 0.019 & 0.004 \\
\hline & $(0.044)$ & $(0.045)$ \\
\hline \multirow[t]{2}{*}{ FDI } & 0.011 & 0.007 \\
\hline & $(0.074)$ & $(0.074)$ \\
\hline ID & No & Yes \\
\hline RG & No & Yes \\
\hline$R$-squared & 0.8560 & 0.8583 \\
\hline Adj R-squared & 0.8544 & 0.8550 \\
\hline
\end{tabular}

Notes: ${ }^{* * *},{ }^{* *},{ }^{*}$ indicate noticeable mean difference under significance level of $1 \%, 5 \%$ and $10 \%$, respectively. 
correlation between independent variables. Specifically, larger value of VIF indicates more serious multicollinearity. There is no multicollinearity when VIF is between 0 and 10 , strong multicollinearity when VIF is between 10 and 100 and serious multicollinearity when VIF is larger than 100. VIFs of all dependent variables in this paper are smaller than 10 and the tolerance $(1 / \mathrm{VIF})$ is larger than 0.1 . Thus there is little multicollinearity in the models specified by this paper. Empirical results in Table 3 indicate that coefficient of DE $\alpha_{5}$ is positive and of great statistical significance while that of IDE $\alpha_{6}$ is of minor statistical significance on the condition that other factors influencing productivity are under control. From the quantitative perspective, the value of $\alpha_{5}$ is about 0.097, which means the productivity level of $\mathrm{DE}$ is $9.7 \%$ higher than that of non-export enterprises. However the coefficient of IDE is positive but not significant in statistics. Thus we can infer that DE mainly accounts for the effect of "learning by exporting" that promotes enterprise productivity while IDE has little impact on enterprise productivity and is not a major mechanism of action in "learning by exporting". Meanwhile, elastic output coefficients of productive inputs (capitals, labors, raw materials and energy) are positive and of great significance, which coincides with the results of previous researches on manufacturing enterprises in developing countries.

As sample enterprises are from different regions and more than one industry, the paper employs region control variable (RG) and industry control variable (ID) to do re-estimation. It's important to note that all enterprises among samples are from major Chinese cities and divided into two types based on their location in administrative centers or not (ID $=1$, enterprises located in provincial capitals or direct-controlled municipalities; ID $=0$, enterprises located in cities except provincial capitals or direct-controlled municipalities). Dummy variables of region and industry are not listed in Table 3 . The empirical results of OLS regression are same with the results when regions and industries are not controlled, which supports our conclusion.

\section{Robustness Check}

Empirical results in model (1) have proved that DE has higher productivity level than non-export enterprises while it is not significant for IDE. Robustness test is further empirical research on DE and IDE. Firstly, DE and non-export enterprises are selected from samples as new research objects. The percentage of direct export in sales volume of enterprises (namely, direct export intensity) is decomposed into five levels ( $0 \%-20 \%, 20 \%$ $40 \%, 40 \%-60 \%, 60 \%-80 \%, 80 \%$ - 100\%) to compare productivities of enterprises with different direct export intensity. Non-export enterprises constitute a reference group.

Take $D E_{j}(j=1,2,3,4,5)$ as the major variable, thus model (1) is modified and get Equation (3) as below:

$$
L n Y_{i}=\alpha_{0}+\alpha_{1} L n L_{i}+\alpha_{2} L n K_{i}+\alpha_{3} L n M_{i}+\alpha_{4} L n E N_{i}+\theta_{j} \sum_{j=1}^{5} D E_{i}+\alpha_{6} I D E_{i}+\sum_{n} \beta_{n} \operatorname{Control}_{n i}+\mu_{i} .
$$

where Control is a control variable reflecting heterogeneity of enterprises and specific variables are same with those in model (1). The results of OLS regression are shown in Table 4.

Table 4. Regression results.

\begin{tabular}{ccc}
\hline Variables & \multicolumn{2}{c}{ Coefficient and significance level } \\
\hline DE1 & $0.165^{* *}$ & $0.137^{*}$ \\
& $(0.082)$ & $(0.081)$ \\
DE2 & 0.017 & 0.022 \\
& $(0.088)$ & $(0.088)$ \\
DE3 & $0.246^{* *}$ & $0.254^{* *}$ \\
& $(0.126)$ & $(0.127)$ \\
DE4 & $0.354^{* *}$ & $0.348^{* *}$ \\
& $(0.153)$ & $(0.154)$ \\
DE5 & -0.032 & -0.036 \\
& $(0.114)$ & $(0.119)$ \\
ID & No & Yes \\
RG & No & Yes \\
R-squared & 0.855 & 0.858 \\
Adj R-squared & 0.853 & 0.854 \\
\hline
\end{tabular}

Notes: ${ }^{* * *},{ }^{* *},{ }^{*}$ indicate noticeable mean difference under significance level of $1 \%, 5 \%$ and $10 \%$, respectively. 


\section{Conclusions}

OLS regression method is used to analyze data of Chinese manufacturing enterprises and several statistical methods are used to test the robustness of analysis results, proving the relationship between direct export and productivity. Just as the prior assumption, we find that DE enterprises have higher productivity level than non-export enterprises but IDE enterprises little differ from non-export enterprises in this term. We attribute this difference to following reasons: first, direct exporters have more access to learning from overseas market and they can update production technologies and improve product quality in an accurate and timely manner via direct contact with international market, cooperators, competitors and consumers. Second, continuous contact with overseas market enhances direct exporters' learning ability. Interaction with technology and market system of many other countries enables direct exports to deeply understand demands of foreign customers and the latest technical information, then signing contracts or starting equity cooperation with leading enterprises in the international market. This paper verifies and testifies the feasibility of this theoretical analysis.

In term of policy, export enterprises usually choose direct export considering healthy and sustainable development and the limitation of indirect export in utilizing foreign market experience, technologies and knowledge to improve productivity. Enterprises still performing indirect export should start transition to direct export in order to improve productivity.

\section{Limitation}

Although empirical analysis in this paper controls many factors influencing enterprise productivity and the robustness of results is tested, there are limitations in samples as the research objects are multi-industry enterprises and there only cross-section data in 2011. If more data are available in following researches, time series can be added to the analysis of panel data and choropleth tools can be used to further study the relationship at higher level. In addition, results of separate researches on different industries are more convincing on the premise of adequate available data.

\section{References}

[1] Bernard, A.B. and Jensen, J.B. (1999) Exceptional Exporter Performance: Cause, Effect, or Both? Journal of International Economics, 47, 1-25. http://dx.doi.org/10.1016/S0022-1996(98)00027-0

[2] Clerides, S.K., Lach, S. and Tybout, J.R. (1998) Is Learning by Exporting Important? Micro-Dynamic Evidence from Colombia, Mexico and Morocco. Quarterly Journal of Economics, 113, 903-947. http://dx.doi.org/10.1162/003355398555784

[3] Melitz, M.J. (2003) The Impact of Trade on Intra-Industry Reallocations and Aggregate Industry Productivity. Econometrica, 71, 1695-1725. http://dx.doi.org/10.1111/1468-0262.00467

[4] Bernard, A.B. and Jensen, J.B. (2004) Exporting and Productivity in the US. Oxford Review of Economic Policy, 20, 343-357. http://dx.doi.org/10.1093/oxrep/grh020

[5] Baldwin, R. (2005) Heterogeneous Firms and Trade: Testable and Untestable Properties of the Melitz Model. NBER Working Paper 5663.

[6] Ghironi, F. and Melitz, M. (2005) International Trade and Macroeconomic Dynamics with Heterogeneous Firms. Quarterly Journal of Economics, 120, 865-915.

[7] Bigsten, A., Collier, P. and Dercon, S. (2004) Do African Manufacturing Firms Learn from Exporting? Journal of Development Studies, 40, 115-141. http://dx.doi.org/10.1080/0022038042000213229

[8] Van Biesebroeck, J. (2005) Exporting Raises Productivity in Sub-Saharan African Manufacturing Firms. Journal of International Economics, 67, 373-391. http://dx.doi.org/10.1016/j.jinteco.2004.12.002

[9] De Loecker, J. (2007) Do Exports Generate Higher Productivity? Evidence from Slovenia. Journal of International Economics, 73, 69-98. http://dx.doi.org/10.1016/j.jinteco.2007.03.003

[10] Greenaway, D. and Kneller, R. (2008) Exporting, Productivity and Agglomeration. European Economic Review, 52, 919-939. http://dx.doi.org/10.1016/j.euroecorev.2007.07.001

[11] Aw, B.Y., Chung, S. and Roberts, M. (2000) Productivity and Turn over Patterns in the Export Market: Firm-Level Evidence from Chinese Taipei and South Korea. World Bank Economic Review, 14, 65-90. http://dx.doi.org/10.1093/wber/14.1.65

[12] Lileeva, A. and Trefler, D. (2010) Improved Access to Foreign Markets Raises Plant-Level Productivity for Some Plants. Quarterly Journal of Economics, 125, 1051-1099. http://dx.doi.org/10.1162/qjec.2010.125.3.1051 
[13] Caves, R.E. (1974) Multinational Firms, Competition and Productivity in Host Country Markets. Economica, 41, 176193. http://dx.doi.org/10.2307/2553765

[14] Globerman, S. (1979) Foreign Direct Investment and Spillover Efficiency Benefits in Canadian Manufacturing Industries. Canadian Journal of Economics, 12, 42-56. http://dx.doi.org/10.2307/134570

[15] Aitken, B. and Harrison, A. (1999) Do Domestic Firms Benefit from Foreign Direct Investment? Evidence from Venezuela. American Economic Review, 89, 605-618. http://dx.doi.org/10.1257/aer.89.3.605

[16] Chen, L. and Luo, C.Y. (2011) FDI Forward and Backward Linkage and Improvement of Productivity in Chinese Manufacturing Enterprises-Researches Conducted on the Basis of Geographical Distance. World Economy Study, 2, 48-53.

[17] Wu, Y.B. (2006) R\&D and Productivity_Empirical Research on Chinese Manufacturing Enterprises. Economic Research Journal, 11, 61-70. 